\title{
MATRIK
}

Jurnal Manajemen dan Teknik Industri-Produksi

Journal homepage: http://www.journal.umg.ac.id/index.php/matriks

\section{Analisis Risiko Dan Penentuan Strategi Mitigasi Pada Proses Produksi Beras}

\author{
Mansur Budi Yahman $^{1^{*}}$, Anggriani Profita ${ }^{2^{*}}$, H. Dharma Widada ${ }^{3 *}$
}

Program Studi Teknik Industri, Fakultas Teknik, Universitas Mulawarman

Jl. Sambaliung No.9, Kampus Gunung Kelua, Samarinda 75119, Kalimantan Timur, Indonesia buddyahman@gmail.com ${ }^{1 *}$, anggi.profita@yahoo.com ${ }^{2 *}$,widada.dharma@gmail.com ${ }^{3 *}$

\begin{tabular}{l}
\hline INFO ARTIKEL \\
\hline $\begin{array}{l}\text { doi: } \mathbf{1 0 . 3 5 0 5 8 7 / M a t r i k} \\
\text { v18i2.589 }\end{array}$ \\
\hline Jejak Artikel : \\
Upload artikel \\
27 Desember 2019 \\
Revisi oleh reviewer \\
20 Maret 2020 \\
Publish \\
30 Maret 2020 \\
\hline
\end{tabular}

Kata Kunci :

Manajemen Risiko, Risiko

Proses Produksi, Strategi

Mitigasi, Fuzzy FMEA, AHP

\section{ABSTRAK}

Pabrik UD Sido Muncul merupakan usaha penggilingan padi yang memproduksi beras siap konsumsiyangdidalam produksinya tidak terlepas dari adanya risiko.Risiko tersebut menyebabkan terganggunya proses produksi dan menyebabkan kerugian seperti terhentinya proses produksi sehingga tidak dapat memenuhi permintaan. Oleh karena itu metode Fuzzy Failure Mode Effect Analysis (Fuzzy FMEA) digunakan untuk mengidentifikasi serta menilai risiko dan Analytical Hierarchy Process (AHP) digunakan untuk menentukan strategi mitigasi prioritas. Identifikasi risiko menggunakan alur proses produksi secara umum yaitu faktor bahan baku (input), proses produksi (process), dan produk jadi (output). Dari hasil pengolahan data fuzzy FMEA didapatkan total 25 risiko dan risiko prioritas dari setiap faktor yaitu risiko pesaing pembeli padi (894) very high, risiko kerusakan pada motor penggerak utama 883 very high, dan risiko pesaing supplier beras (748) high-very high. Untuk memitigasi risiko prioritas maka dikembangkan 7 alternatif strategi dan dilakukan pemilihan strategi mitigasi prioritas dengan AHP. Adapun strategi mitigasi prioritas yang terpilih untuk setiap faktor risiko yaitu strategi menjalin kemitraan $(0,731)$ untuk faktor risiko input, strategi pemeliharaan mesin secara rutin $(0,637)$ untuk faktor risiko process dan strategi menjaga kualitas produk $(0,637)$ untuk faktor risiko output. 


\section{Pendahuluan}

Beras merupakan kebutuhan pangan pokok bagi sebagian besar masyarakat Indonesia. Ketergantungan masyarakat di Indonesia sangat tinggi terhadap beras, hal tersebut akan menjadi suatu masalah jika ketersediaan beras sudah tidak dapat tercukupi. Produksi padi di Indonesia dari Januari hingga September 2018 jikadikonversikan menjadi beras dengan angka konversi Gabah Kering Giling (GKG) ke beras tahun 2018 setara dengan 28,47 juta ton beras. Sementara itu, potensi produksi pada bulan Oktober hingga Desember 2018 masingmasing sebesar 1,52 juta ton, 1,20 juta ton, dan 1,22 juta ton. Dengan demikian, perkiraan total produksi beras tahun 2018 adalah sebesar 32,42 juta ton[1].

Kalimantan Timur (Kaltim) dinilai berpotensi menjadi salah satu lumbung pangan nasional karena disokong lahan pertanian seluas 20 ribu hektare[2]. Produksi padi di Kaltim pada tahun 2018 diperkirakan sebesar 241,40 ribu ton [3]. Penajam Paser Utara (PPU) memiliki kontribusi terhadap pencapaian swasembada pangan khususnya padi dan menjadi salah satu sentra produksi padi tertinggi di Kaltim dengan jumlah produksi padi sebesar 37,20 ribu ton pada tahun 2018, selain Kabupaten Kutai Kartanegara dan Berau [3].

Untuk menunjang produksi dan kebutuhan beras diperlukan pabrik penggilingan padi yang merupakan rangkaian mesin yang memiliki fungsi untuk memisahkan bulir beras dengan kulitnya dari bentuk gabah kering sampai dengan menjadi beras siap konsumsi.Pabrik penggilingan padi UD Sido Muncul merupakan sebuah usaha penggilingan padi yang memproduksi beras siap konsumsi, terletak di desa Labangka, Kecamatan Babulu, PPU. Dalam proses produksi beras UD Sido Muncul memiliki bahan baku gabah yang diambil langsung dari para petani, diproses dengan rangkaian mesin penggiling padi dan hasil produksi beras dipasarkan ke berbagai agen beras dan konsumen yang datang langsung ke pabrik penggilingan UD Sido Muncul.
Proses produksi beras yang dilakukan UD Sido Muncul tidak terlepas dari risiko-risiko yang menyebabkan terganggunya proses produksi beras. Risiko yang terjadi seperti halnya keterlambatan bahan baku gabah dalam proses produksi, terjadinya kerusakan alat pada mesin penggilingan padi, beras hasil produksi yang memiliki kualitas yang tidak baik seperti biji beras yang tidak utuh atau hancur dan sebagainya. Risiko-risiko yang terjadi dapat menyebabkan beberapa kerugian seperti terganggunya proses produksi beras sehingga tidak dapat memenuhi kebutuhan permintaan.Risiko produksi merupakan suatu keadaan yang dapat merugikan pencapaian tujuan dan sasaran organisasi bisnis[4].

Berdasarkan permasalahan yang terjadi, perlu dilakukan penelitianmengenai risiko proses produksi beras yang terjadi pada UD Sido Muncul. Dalam penelitian ini risiko dikelola dengan menggunakan metode Fuzzy Failure Mode Effect Analysis (Fuzzy FMEA) dan Analytical Hierarchy Process (AHP) untuk mengidentifikasi risiko-risiko yang mungkin terjadi dan menentukan strategi mitigasi penanganan risiko untuk menurunkan tingkat frekuensi terjadinya risiko dan dampak dari risiko pada proses produksi beras UD Sido Muncul.

\section{Metode Penelitian}

\subsection{Manajemen Risiko}

Manajemen risiko adalah suatu kegiatan dalam mengukur atau menilai suatu risiko dimana dari kegiatan tersebut akan dikembangkan strategi pengelolaan terhadap risiko tersebut. Strategi yang bisa digunakan antara lain dengan memindahkan risiko kepada kegiatan atau subyek lain, menghindar dari risiko tersebut, mengurangi efek negatif yang ditimbulkan dari risiko, dan dapat juga menampung konsekuensi baik sebagian atau keseluruhan dari risiko tertentu [5]. Manajemen risiko adalah kegiatan atau proses manajemen yang terarah bersifat proaktif yang ditujukan untuk mengakomodasi kemungkinan kegagalan salah satu atau sebagian dari sebuah 
instrumen [4]. Fokus manajemen risiko yang baik, adalah mengidentifikasi, mengelola dan mengendalikan risiko dengan baik.

\subsection{Failure Mode Effect Analysis (FMEA)}

Metode Failure Mode Effect Analysis (FMEA) adalah suatu prosedur terstruktur untuk mengidentifikasi dan mencegah sebanyak mungkin mode kegagalan (failure mode) dengan sekala prioritas [4]. FMEA dapat dipakai baik untuk menganalisis mode kegagalan pada proses maupun produk. Pembuatan metode FMEA bertujuan untuk mengidentifikasi dan menilai risiko-risiko yang memiliki hubungan dengan potensi kegagalan[4].

Hasil akhir dari metode FMEA adalah Risk Priority Number (RPN) atau angka risiko prioritas. Nilai RPN dihitung berdasarkan perkalian antara tiga peringkat kuantitatif yaitu efek/pengaruh, penyebab, dan deteksi pada setiap proses atau dikenal dengan perkalian $\mathrm{S}$, $\mathrm{O}, \mathrm{D}$ (severity, occurance, detection) [4].

a. Severity (Tingkat Kerusakan)

Dalam menentukan tingkat severity) ini dapat ditentukan seberapa serius kerusakan yang dihasilkan dengan terjadinya kegagalan proses dalam hal operasi perawatan dan kegiatan operasional pabrik[6].

b. Occurrence (Tingkat Frekuensi)

Dalam menentukan occurrence ini dapat ditentukan seberapa banyak gangguan yang dapat menyababkan sebuah kegagalan pada kegiatan operasional pabrik[6].

c. Detection(Tingkat Deteksi)

Dalam menentukan tingkat deteksi ini dapat ditentukan bagaimanakegagalan tersebut dapat diketahui sebelum terjadi. tingkat deteksi juga dapat dipengaruhi dari banyaknya kontrol yang mengatur jalanya proses. semakin banyak kontrol dan prosedur yang mengatur jalanya kegiatan operasional pabrik maka diharapkan tingkat deteksi dari kegagalan dapat semakin tinggi[6].

\subsection{Logika Fuzzy}

Fuzzy atau Fuzzy Logic merupakan suatu proses pengambilan keputusan yang berbasis aturan dengan maksud untuk memberikan solusi terhadap permasalahan yang terjadi apabila sistem tersebut sulit untuk dimodelkan atau dengan kata lain adanya ambiguitas dan ketidak jelasan yang berlimpah[5].

Dasar penentuan fuzzy logic adalah persamaan logika yang berasal dari pemikiran yang mengidentifikasi dan juga bagaimanamengambil keuntungan dari grayness yang terjadi antara 2 ekstrem. Sistem fuzzy logic terdiri dari dua hal utama yaitu himpunan fuzzy dan aturan-aturan fuzzy. Subset fuzzy adalah himpunan bagian yang berbeda dari dua variabel yaitu variabel input dan variabel output. Sedangkan aturan fuzzy, berkaitan dengan variabel input dan variabel output yang dihubungkan melalui subset [5].

Penelitian dengan menggunakan logika fuzzy akan memperoleh hasil yang lebih akurat dibandingkan dengan menggunakan metode FMEA tradisional[7].

\subsection{Fuzzy Failure Mode Effect Analysis(FMEA)}

Fuzzy FMEA merupakan pengembangan dari metode FMEA yang memberikan fleksibilitas untuk menampung ketidakpastian akibat samarnya informasi yang dimiliki maupun unsur preferensi yang subjektif yangdigunakan dalam penilaian terhadap mode kegagalan yang terjadi [7].Penambahan konsepFuzzy pada algoritma FMEA memungkinkan data yang digunakan berupa data linguistik ataupun data numerik yang akan mempunyai nilai membership pada setiap atributnya [8].

\subsection{Analytical Hierarchy Process (AHP)}

Analytical Hierarchy Process (AHP) merupakan suatu metode pendukung keputusan yang dikembangkan oleh Thomas L. Saaty. Model pendukung keputusan ini akan menguraikan masalah multi faktor atau multi kriteria yang kompleks menjadi suatu 
hierarki[9]. Hierarki didefinisikan sebagai suatu representasi dari sebuah permasalahan yang kompleks dalam suatu struktur multilevel dimana level pertama adalah tujuan, yang diikuti level faktor, kriteria, sub kriteria, dan seterusnya hingga level terakhir dari alternatif.Pada metode AHP terdapat penilaian terhadap setiap kriteria dan alternatif yang dilakukan dengan perbandingan berpasangan[9].

Prinsip kerja AHP adalah penyederhanaan suatu persoalan kompleks yang tidak terstruktur, stratejik, dan dinamik menjadi bagian-bagiannya, serta menata dalam suatu hierarki. Kemudian tingkat kepentingan setiap variabel diberi nilai numerik secara subjektif tentang arti penting variabel tersebut secara relatif dibandingkan dengan variabel lain. Dari berbagai pertimbangan tersebut kemudian dilakukan sintesa untuk menetapkan variabel yang memiliki prioritas tinggi dan berperan untuk mempengaruhi hasil pada sistem tersebut[10]. Terdapat tiga prinsip dalam memecahkan persoalan dengan AHP, yaitu prinsip menyusun hirarki (decomposition), prinsip menentukan prioritas (comparative Judgement), dan prinsip konsistensi logis (logical consistency)[10].

\subsection{Tempat dan Lokasi Penelitian}

Penelitian ini dilaksanakan pada usaha pabrik penggilingan padi UD Sido Muncul yang merupakan sebuah uaha penggilingan padi yang memproduksi beras siap konsumsi. Usaha ini terletak di desa Labangka, Kecamatan Babulu, Penajam Paser Utara.

\subsection{Tahapan Penelitian}

Penelitian ini terdiri dalam beberapa tahapan diantaranya tahap persiapan, tahap pengumpulan data, tahap pengolahan data, tahap analisis dan pembahasan dan tahap penutup yang berisi penarikan kesimpulan dan saran.

Data yang diperlukan dalam penelitian meliputi data primer dan sekunder. Data primer didapatkan dari hasil observasi, wawancara dan pengisian kuesioner.Data sekunder didapatkan dari media perantara atau secara tidak langsung yang berupa buku, catatan, bukti yang telah ada, atau arsip baik yang dipublikasikan maupun yang tidak dipublikasikan secara umum.

Berdasarkan data yang telah dikumpulkan maka selanjutnya dilakukan pengolahan data. Pada tahap pengolahan data dibagi menjadi dua bagian pengolahan data yaitu pengolahan data dengan metode fuzzy FMEA dan AHP

1. Pengolahan data dengan metode Fuzzy FMEA

Pengolahan data dengan metode Fuzzy FMEA dilakukan untuk mendapatkan nilai FRPN (Fuzzy Risk Priority Number),tahapan yang dilakukan dalam perhitungan nilai FRPN adalah sebagai berikut:

a. Pembentukan himpunan fuzzy,

b. Penentuan aturan fuzzy,

c. Aplikasi fungsi implikasi,

d. Komposisi aturan, dan

e. Proses defuzzifikasi

Setelah didapatkan nilai FRPN selanjutnya dilakukan pemilihan tingkat risiko dengan melihat nilai dan rangking teringgi dari FRPN dari setiap faktor risiko yang akan dijadikan prioritas. Tahap selanjutnya dilakukan penentuan alternatif strategi berdasarkan risiko prioritas yang didapatkan dari nilai dan rangking teringgi FRPN dari setiap faktor risiko yang dijadikan risiko prioritas untukditanggulangi dan dijadikan sebagai landasan dalam penentuan strategi mitigasi.

2. Pengolahan data dengan metode AHP

Pengolahan data dengan metode AHP dilakukan untuk menentukan keputusan pemilihan prioritas strategi mitigasi. Langkah-langkah dalam menentukan keputusan pemilihan prioritas strategi mitigasi adalah sebagai berikut:

a. Penentuan alternatif strategi,

b. Menyusun struktur hirarki,

c. Membentuk matriks perbandingan berpasangan,

d. Normalisasi dan uji konsistensi dan

e. Penenentuan kriteria prioritas. 
Dalam penentuan kriteria prioritas strategi mitigasi dilakukan dengan melihat nilai bobot tertinggi dari masing-masing kriteria yang perlu diperhatikan karena merupakan prioritas utama.

\section{Hasil dan Pembahasan}

\subsection{Gambaran Umum Perusahaan}

UD. Sido Muncul merupakan sebuah usaha pabrik penggilingan padi yang memproduksiberas siap konsumsi. Pabrik penggilingan padi UD. Sido Muncul didirikan pada tahun 2012, bertempat di Desa Labangka Barat, RT 007, Kecamatan Babulu, Kabupaten Penajam Paser Utara.

Dalam proses produksi beras UD. Sido Muncul mendapatkan bahan baku padi langsung dari petani kemudian dilakukan proses produksi dalam beberapa rangkaian alat penggilingan padi sehingga menghasilkan beras siap konsumsi dan dilakukan pemasaran.

\subsection{Identifikasi dan Penilaian Risiko}

Identifikasi risiko dilakukan dengan melalui studi literatur, observasi dan wawancara kepada responden yaitu pemilik perusahaan. Berdasarkan hasil identifikasi proses produksi beras yang dilakukan UD Sido Muncul secara umum dapat dibagi menjadi tiga faktor risiko yaitu faktor risiko pada bahan baku (input), proses produksi (process), dan produk jadi (output). Data risiko yang telah didapatkan kemudian dilakukan penilaian severity, occurrence, dan detection oleh pemilik perusahaan. Adapun risiko-risiko yang didapatkan dari setiap faktor risko berserta hasil penilaian dapat dijabarkan pada Tabel 1 .

Tabel 1. Hasil Penilaian Kuesioner Risiko FMEA

\begin{tabular}{|c|c|c|c|c|c|}
\hline No & Faktor Risiko & Risiko & $\mathbf{S}$ & $\mathbf{O}$ & D \\
\hline \multirow{8}{*}{1} & \multirow{8}{*}{$\begin{array}{l}\text { Bahan Baku } \\
\quad \text { (input) }\end{array}$} & Gagal panen & 5 & 4 & 5 \\
\hline & & Keterlambatan waktu panen & 2 & 2 & 2 \\
\hline & & Kadar air padi tinggi & 4 & 8 & 8 \\
\hline & & Kualitas padi kurang baik akibat serangan hama & 3 & 5 & 3 \\
\hline & & Padi tercampur dengan padi jenis lainnya & 2 & 3 & 6 \\
\hline & & Pola tanam padi & 3 & 3 & 1 \\
\hline & & Pesaing pembeli padi & 5 & 9 & 10 \\
\hline & & Jenis padi tidak sesuai dengan permintaan & 3 & 5 & 8 \\
\hline \multirow{12}{*}{2} & \multirow{12}{*}{$\begin{array}{l}\text { Proses Produksi } \\
\quad \text { (process) }\end{array}$} & Lingkungan kerja tidak nyaman & 2 & 10 & 1 \\
\hline & & Keterlambatan proses produksi & 2 & 5 & 4 \\
\hline & & Bahan bakar habis pada saat proses produksi & 7 & 6 & 1 \\
\hline & & Pemadaman listrik & 2 & 5 & 10 \\
\hline & & Kerusakan pada motor penggerak utama & 8 & 7 & 10 \\
\hline & & Kerusakan rangkaian alat penggilingan padi & 6 & 7 & 10 \\
\hline & & $\begin{array}{l}\text { Belt penghubung motor utama dengan rangkaian } \\
\text { alat penggilingan putus }\end{array}$ & 6 & 7 & 6 \\
\hline & & Pemanasan oven tidak menyeluruh & 3 & 5 & 5 \\
\hline & & Kerusakan pada mesin oven & 4 & 4 & 10 \\
\hline & & Mesin dan alat bantu pengemasan rusak & 3 & 6 & 10 \\
\hline & & Bulir padi hancur pada saat penggilingan & 3 & 4 & 3 \\
\hline & & Kemasan beras habis pada saat proses produksi & 2 & 6 & 2 \\
\hline \multirow{3}{*}{3} & \multirow{3}{*}{$\begin{array}{l}\text { Produk jadi } \\
\text { (output) }\end{array}$} & $\begin{array}{l}\text { Kerusakan beras dan kemasan pada saat } \\
\text { penyimpanan }\end{array}$ & 2 & 6 & 4 \\
\hline & & $\begin{array}{l}\text { Keterlambatan pengiriman beras kepada } \\
\text { pelanggan }\end{array}$ & 3 & 6 & 5 \\
\hline & & Pesaing supplier beras & 5 & 8 & 10 \\
\hline
\end{tabular}


Lanjutan 1. Hasil Penilaian Kuesioner Risiko FMEA

\begin{tabular}{|c|c|c|c|c|c|}
\hline No & Faktor Risiko & Risiko & $\mathbf{S}$ & $\mathbf{O}$ & D \\
\hline & \multirow{2}{*}{$\begin{array}{l}\text { Produk jadi } \\
\text { (output) }\end{array}$} & $\begin{array}{l}\text { Beras hasil produksi tidak sesuai dengan } \\
\text { permintaan pelanggan }\end{array}$ & 3 & 4 & 8 \\
\hline & & $\begin{array}{l}\text { Telatnya pembayaran pelanggan dari waktu yang } \\
\text { telah ditentukan }\end{array}$ & 5 & 7 & 10 \\
\hline
\end{tabular}

Sumber: Hasil Pengolaham Data 2019

\subsection{Pemeringkatan dan Penentuan Risiko Prioritas}

Pemeringkatan risiko dapat dilakukan setelah dilakukannya pengolahan data dan didapatkannya nilai FRPN dari setiap risiko.
Pemeringkatan risiko dilakukan berdasarkan hasil nilai FRPN terbesar sampai dengan FRPN terkecil dari masing-masing faktor risiko. Perangkingan risiko berdasarkan nilai FRPN dapat dilihat pada Tabel 2.

Tabel 2. Perangkingan Risiko Berdasarkan Nilai FRPN

\begin{tabular}{|c|c|c|c|c|c|}
\hline No & Faktor Risiko & Risiko & FRPN & Kategori & Rangking \\
\hline \multirow{8}{*}{1} & \multirow{8}{*}{$\begin{array}{l}\text { Bahan Baku } \\
\quad \text { (input) }\end{array}$} & Pesaing pembeli padi & 894 & $\mathrm{VH}$ & 1 \\
\hline & & Kadar air padi tinggi & 685 & $\mathrm{H}-\mathrm{VH}$ & 2 \\
\hline & & Gagal panen & 509 & $\mathrm{H}$ & 3 \\
\hline & & Jenis padi tidak sesuai dengan permintaan & 404 & M-H & 4 \\
\hline & & $\begin{array}{l}\text { Kualitas padi kurang baik akibat serangan } \\
\text { hama }\end{array}$ & 356 & M-H & 5 \\
\hline & & Pola tanam padi & 205 & L-M & 6 \\
\hline & & Padi tercampur dengan padi jenis lainnya & 202 & L-M & 7 \\
\hline & & Keterlambatan waktu panen & 154 & L-M & 8 \\
\hline \multirow{12}{*}{2} & \multirow{12}{*}{$\begin{array}{c}\text { Proses } \\
\text { Produksi } \\
\text { (process) }\end{array}$} & Kerusakan pada motor penggerak utama & 883 & $\mathrm{VH}$ & 1 \\
\hline & & $\begin{array}{l}\text { Kerusakan rangkaian alat penggilingan } \\
\text { padi }\end{array}$ & 705 & $\mathrm{H}-\mathrm{VH}$ & 2 \\
\hline & & $\begin{array}{l}\text { Belt penghubung motor utama dengan } \\
\text { rangkaian alat penggilingan putus }\end{array}$ & 648 & $\mathrm{H}-\mathrm{VH}$ & 3 \\
\hline & & $\begin{array}{l}\text { Bahan bakar habis pada saat proses } \\
\text { produksi }\end{array}$ & 539 & $\mathrm{H}$ & 4 \\
\hline & & Kerusakan pada mesin oven & 479 & $\mathrm{H}$ & 5 \\
\hline & & Pemanasan oven tidak menyeluruh & 401 & M-H & 6 \\
\hline & & Mesin dan alat bantu pengemasan rusak & 377 & $\mathrm{M}-\mathrm{H}$ & 7 \\
\hline & & Bulir padi hancur pada saat penggilingan & 356 & M-H & 8 \\
\hline & & Pemadaman listrik & 252 & $\mathrm{M}$ & 9 \\
\hline & & Keterlambatan proses produksi & 233 & L-M & 10 \\
\hline & & $\begin{array}{l}\text { Kemasan beras habis pada saat proses } \\
\text { produksi }\end{array}$ & 184 & L-M & 11 \\
\hline & & Lingkungan kerja yang tidak nyaman & 173 & L-M & 12 \\
\hline \multirow{4}{*}{3} & \multirow{4}{*}{$\begin{array}{l}\text { Produk jadi } \\
\text { (output) }\end{array}$} & Pesaing supplier beras & 748 & $\mathrm{H}-\mathrm{VH}$ & 1 \\
\hline & & $\begin{array}{l}\text { Telatnya pembayaran pelanggan dari } \\
\text { waktu yang telah ditentukan }\end{array}$ & 670 & $\mathrm{H}-\mathrm{VH}$ & 2 \\
\hline & & $\begin{array}{l}\text { Beras hasil produksi tidak sesuai dengan } \\
\text { permintaan pelanggan }\end{array}$ & 404 & M-H & 3 \\
\hline & & $\begin{array}{l}\text { Keterlambatan pengiriman beras kepada } \\
\text { pelanggan }\end{array}$ & 401 & M-H & 4 \\
\hline
\end{tabular}


Lanjutan Tabel 2. Perangkingan Risiko Berdasarkan Nilai FRPN

\begin{tabular}{|c|c|c|c|c|c|}
\hline No & Faktor Risiko & Risiko & FRPN & Kategori & Rangking \\
\hline & $\begin{array}{l}\text { Produk jadi } \\
\text { (output) }\end{array}$ & $\begin{array}{l}\text { Kerusakan beras dan kemasan pada saat } \\
\text { penyimpanan }\end{array}$ & 234 & L-M & 5 \\
\hline
\end{tabular}

Sumber: Hasil Pengolahan Data 2019

Berdasarkan hasil pemeringkatan risiko didapatkan risiko tertinggi pada faktor risiko bahan baku (input) yaitu risiko pesaing pembeli padi dengan nilai FRPN sebesar 894 dan termasuk kedalam kategori risiko sangat tinggi (very high), pada faktor risiko proses produksi (proses) yaitu risiko kerusakan pada motor penggerak utama dengan nilai FRPN sebesar 883 dan termasuk kedalam kategori risiko sangat tinggi (very high), dan pada faktor risiko produk jadi (output) yaitu risiko pesaing supplier beras dengan nilai FRPN sebesar 748 dan termasuk kedalam kategori risiko tinggi-sangat tinggi (high-very high).

Risiko tertinggi yang didapatkan dari hasil pemeringkatan risiko merupakan risiko yang akan dijadikan sebagai risiko prioritas untuk ditindaklanjuti dan dijadikan sebagai acuan dalam penentuan strategi mitigasi untuk meminimasi risiko pada proses produksi beras.

Untuk menganalisis risiko prioritas yang telah ditentukan yaitu risiko pesaing pembeli padi, risiko pesaing pembeli padi, dan risiko pesaing supplier beras dari masing-masing faktor risiko yang dapat menghambat proses produksi, maka perlu untuk mengetahui potential effect of failure, potential cause of failure, dan detection atau current control dari setiap risiko prioritas. Hasil dari potential effect of failure, potential cause of failure, dan detection atau current control dapat dilihat pada Tabel 3.

Tabel 3. Risiko Prioritas Pada Faktor Bahan Baku, Proses Produksi, dan Produk Jadi

\begin{tabular}{|c|c|c|c|c|c|c|c|}
\hline $\begin{array}{c}\text { Failure } \\
\text { Mode }\end{array}$ & $\begin{array}{c}\text { Potential Effect } \\
\text { of Failure }\end{array}$ & $\mathbf{S}$ & $\begin{array}{c}\text { Potential Cause } \\
\text { of Failure }\end{array}$ & $\mathbf{O}$ & $\begin{array}{c}\text { Detection / } \\
\text { Current Control }\end{array}$ & D & FRPN \\
\hline (1) & (2) & (3) & (4) & (5) & (6) & (7) & (8) \\
\hline $\begin{array}{l}\text { Pesaing } \\
\text { pembeli } \\
\text { padi }\end{array}$ & $\begin{array}{l}\text { - Keterlambatan } \\
\text { proses } \\
\text { produksi } \\
\text { - Tingkat } \\
\text { produksi } \\
\text { menurun } \\
\text { - Proses } \\
\text { produksi } \\
\text { berhenti }\end{array}$ & 5 & $\begin{array}{l}\text { - Bertambahnya } \\
\text { pesaing } \\
\text { - Tidak adanya } \\
\text { ikatan kerja } \\
\text { sama dengan } \\
\text { petani }\end{array}$ & 9 & $\begin{array}{l}\text { - Melakukan } \\
\text { kerja sama } \\
\text { dengan petani } \\
\text { - Memberikan } \\
\text { kepercayaan } \\
\text { kepada petani } \\
\text { - Meningkatkan } \\
\text { promosi }\end{array}$ & 10 & 894 \\
\hline
\end{tabular}

Sumber: Hasil Pengolahan Data 2019 
Lanjutan Tabel 3. Risiko Prioritas Pada Faktor Bahan Baku, Proses Produksi, dan Produk Jadi

\begin{tabular}{|c|c|c|c|c|c|c|c|}
\hline $\begin{array}{l}\text { Failure } \\
\text { Mode }\end{array}$ & $\begin{array}{c}\text { Potential Effect } \\
\text { of Failure }\end{array}$ & $\mathbf{S}$ & $\begin{array}{c}\text { Potential Cause } \\
\text { of Failure }\end{array}$ & $\mathbf{O}$ & $\begin{array}{c}\text { Detection / } \\
\text { Current Control }\end{array}$ & D & $F R P N$ \\
\hline \multirow[t]{2}{*}{ (1) } & (2) & (3) & (4) & (5) & (6) & (7) & (8) \\
\hline & $\begin{array}{l}\text { - Penurunan } \\
\text { jumlah bahan } \\
\text { baku }\end{array}$ & & & & & & \\
\hline $\begin{array}{l}\text { Kerusakan } \\
\text { pada motor } \\
\text { penggerak } \\
\text { utama }\end{array}$ & $\begin{array}{l}\text { - Keterlambatan } \\
\text { proses } \\
\text { produksi } \\
\text { - Proses } \\
\text { produksi } \\
\text { berhenti } \\
\text { - Hasil produksi } \\
\text { menurun } \\
\text { - Pengeluaran } \\
\text { biaya } \\
\text { perbaikan } \\
\text { mesin }\end{array}$ & 8 & $\begin{array}{l}\text { - Tidak } \\
\text { melakukan } \\
\text { perawatan } \\
\text { rutin terhadap } \\
\text { mesin } \\
\text { - Penggunaan } \\
\text { mesin secara } \\
\text { terus menerus }\end{array}$ & 7 & $\begin{array}{l}\text { - Melakukan } \\
\text { perawatan } \\
\text { mesin secara } \\
\text { rutin } \\
\text { - Menyediakan } \\
\text { spare part } \\
\text { mesin } \\
\text { - Menjalankan } \\
\text { mesin sesuai } \\
\text { intruksi kerja }\end{array}$ & 10 & 883 \\
\hline $\begin{array}{l}\text { Pesaing } \\
\text { supplier } \\
\text { beras }\end{array}$ & $\begin{array}{l}\text { - Penurunan } \\
\text { permintaan } \\
\text { - Penurunan } \\
\text { penjualan } \\
\text { - Penurunan } \\
\text { omzet }\end{array}$ & 4 & $\begin{array}{l}\text { - Bertambahnya } \\
\text { pesaing } \\
\text { - Tidak adanya } \\
\text { ikatan } \\
\text { kerjasama } \\
\text { dengan } \\
\text { pelanggan } \\
\text { - Kualitas beras } \\
\text { yang tidak baik }\end{array}$ & 9 & $\begin{array}{l}\text { - Menjalin } \\
\text { kerjasama } \\
\text { dengan } \\
\text { pelanggan } \\
\text { - Meningkatkan } \\
\text { promosi } \\
\text { - Menjaga } \\
\text { kualitas beras }\end{array}$ & 10 & 748 \\
\hline
\end{tabular}

Sumber: Hasil Pengolahan Data 2019

\subsection{Penentuan Alternatif Strategi}

Setelah diketahui potential effect of failure, potential cause of failure, dan detection atau current control dari masing-masing risiko prioritas, maka tahap selanjutnya adalah dilakukan penentuan strategi mitigasi. Strategi mitigasi yang ditetapkan untuk menanggulangi risiko yang sesuai dengan risiko prioritas yang didapatkan dari setiap faktor risiko dan alternatif strategi didapatkan berdasarkan pertimbangan studi literatur peneliti terdahulu terhadap risiko risiko prioritas pada Tabel 3 . Tujuan dari penentuan dan pengembangan strategi tersebut untuk meminimasi terjadinya risiko dengan menurunkan frekuensi terjadinya risiko atau menurunkan dampak yang disebabkan dari risiko pada proses produksi beras. Adapun alternatif strategi yang ditentukan adalah sebagai berikut:
1. Menjalin kemitraan dengan pelaku bisnis lainnya,

2. Membangun citra baik dalam industri,

3. Melakukan pemeliharaan mesin secara rutin,

4. Melakukan penyediaan spare part mesin,

5. Penerapan intruksi kerja pengoperasian mesin,

6. Meningkatkan promosi dan

7. Menjaga kualitas produk.

Berdasarkan strategi mitigasi risiko yang telah ditentukan selanjutnya dilakukan pemilihan strategi yang tepat untuk menanggulangi atau meminimasi terjadinya kegagalan pada proses produksi beras dari setiap faktor risiko. Setelah mentukan startegi untuk menanggulangi risiko prioritas selanjutnya dilakukan pengolahan data AHP untuk menentukan startegi prioritas. 
Berdasarkan perhitungan yang dilakukan dari hasil penilaian kuesioner maka didapatkan nilai dari setiap kriteria dan alternatif strategi.Adapun struktur hirarki dan hasil perhitungan bobot kriteria dan subkriteria alternatif strategi yang didapatkan dapat dilihat pada struktur hirarki minimasi risiko kegagalan proses produksi beras pada Gambar 1 .

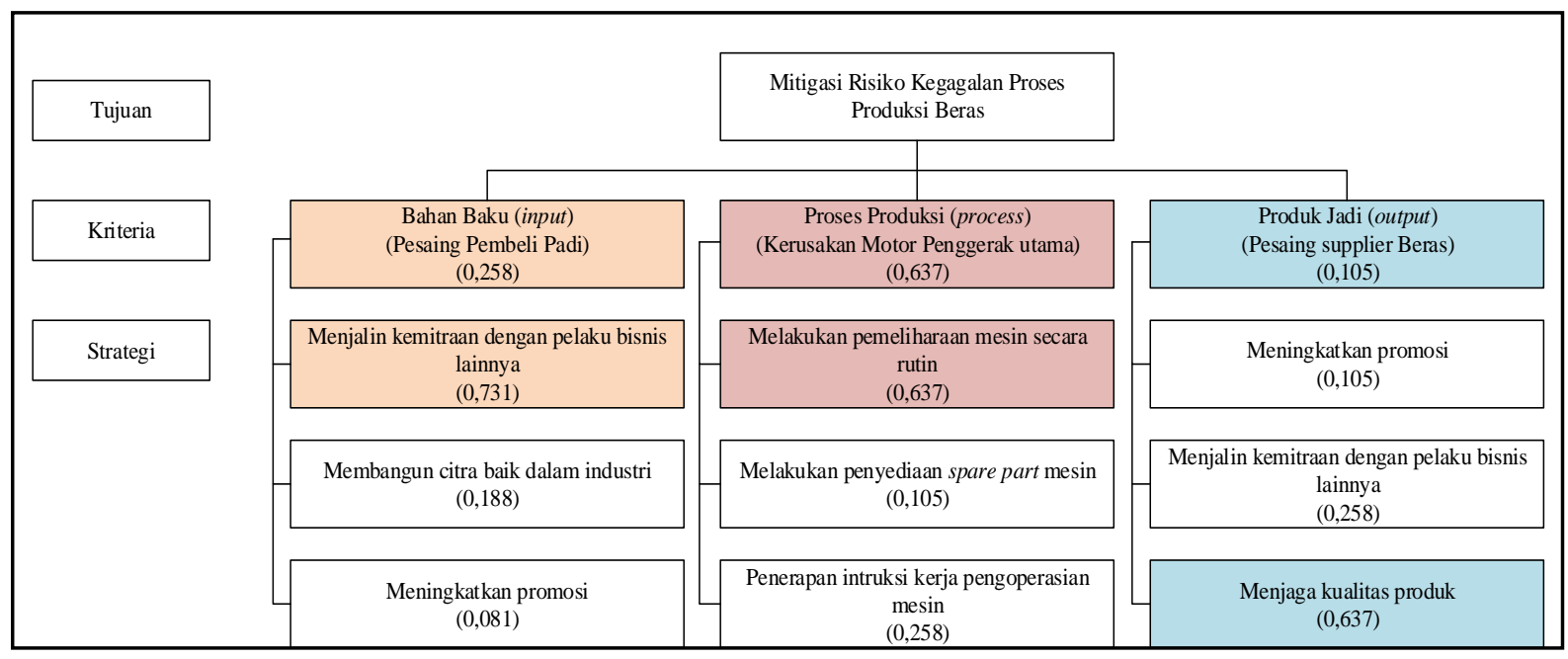

Gambar 1. Struktur Hirarki Strategi Mitigasi Risiko Kegagalan Proses Produksi

\subsection{Prioritas Mitigasi Pada Faktor Kriteria}

Dari hasil penilaian dan pengolahan data pada tingkat kriteria didapatkan bobot nilai tertinggi yaitu sebesar 0,673 pada kriteria proses produksi (process). Risiko pada kriteria proses produksi (process) merupakan risiko prioritas utama yang harus dilakukan mitigasi, karena jika risiko pada faktor proses produksi (process) yaitu kerusakan pada mesin penggerak utama terjadi maka akan menyebabkan lebih banyak dampak kerugian seperti pengeluaran biaya perbaikan mesin, waktu perbaikan mesin yang tidak dapat diperkirakan, terhentinya seluruh rangkaian proses produksi dan penurunan hasil produksi.

Bobot tertinggi kedua yaitu sebesar 0,258 pada kriteria bahan baku (input). Risiko pada kriteria bahan baku (input) merupakan risiko prioritas kedua yang harus dilakukan mitigasi, karena jika risiko pada faktor bahan baku (input) yaitu adanya pesaing pembeli padi terjadi maka akan menyebabkan beberapa dampak kerugian seperti tidak mendapatkan bahan baku, berhentinya proses produksi, dan penurunan hasil produksi.

Bobot tertinggi ketiga yaitu sebesar 0,105 pada kriteria produk jadi (output). Risiko kriteria produk jadi (output) merupakan risiko prioritas ketiga yang harus dilakukan mitigasi, karena jika risiko pada faktor produk jadi (output) yaitu adanya pesaing supplier beras terjadi maka akan menyebabkan dampak kerugian seperti penurunan permintaan dan penjualan. Dampak kerugian yang disebabkan risiko pada kriteria produk jadi (output) lebih rendah dibandingkan dampak yang terjadi pada faktor risiko bahan baku (input) dan faktor risiko proses produksi (process).

\subsection{Prioritas Alternatif Strategi Mitigasi pada Risiko Bahan Baku (input)}

Dari hasil penilaian dan pengolahan data pada alternatif strategi berdasarkan kriteria bahan baku (input) didapatkan bobot tertinggi yaitu sebesar 0,731 pada alternatif strategi menjalin kemitraandengan pelaku bisnis lainnya, alternatif strategi tersebut merupakan alternatif strategi prioritas yang paling berpengaruh dan paling penting untuk memitigasi risiko pada faktor bahan baku (input) yaitu adanya pesaing pembeli padi.

Kemitraan adalah bentuk kerjasama usaha antar dua pihak dengan dengan saling menguntungkan dan meningkatkan pendapatan sehingga tercapai tujuan usaha[11]. Strategi kemitraan ini juga dapat membantu produsen 
dan distributor, agen atau riteler untuk dapat bekerjasama dengan saling membutuhkan dan menguntungkan[4]. Dalam hubungan kemitraan dalam dunia usaha antar pelaku usaha harus didasarkan pada ikatan usaha yang saling menguntungkan dalam hubungan kerja sinergis[4]. Oleh karena itu dengan menjalinikatan kerjasama antara UD Sido Muncul dengan para petani akan mengatasi risiko adanya pesaing pembeli padi dan mendapatkan keuntungan seperti mudahnya UD Sido Muncul untuk mendapatkan bahan baku dari para petani sehingga ketersediaan bahan baku akan stabil dan proses produksi akan berjalan dengan lancar.

\subsection{Prioritas Alternatif Strategi Mitigasi pada Risiko Proses Produksi (process)}

Dari hasil penilaian dan pengolahan data pada alternatif strategi berdasarkan kriteria proses produksi (process) didapatkan bobot tertinggi yaitu sebesar 0,637 pada alternatif strategi melakukan pemeliharaan mesin secara rutin, alternatif strategi tersebut merupakan alternatif strategi prioritas yang paling berpengaruh dan paling penting untuk memitigasi risiko pada faktor proses produksi (process) yaitu kerusakan pada motor penggerak utama.

Salah satu faktor produksi yang harus dioptimalkan penggunaannya yaitu mesin produksi. Mesin yang digunakan dalam kegiatan produksi harus mampu beroperasi dengan optimal. Pengoperasian mesin dikatakan optimal apabila nilai downtime-nya minimum. Untuk dapat menjamin pengoperasian mesin yang optimal, diperlukan suatu sistem perawatan dan pemeliharaan mesin yang tepat. Sistem perawatan mesin yang tepat merupakan sistem perawatan yang dapat memberikan jadwal perawatan dengan minimum dowtime sehingga memberikan total biaya yang minimum[12]. Oleh karena itu dengan melakukan perawatan mesin secara rutin dan terjadwal akan mengatasi risiko terjadinya kerusakan pada motor penggerak utama, karena hal tersebut dapat membantu mengurangi pemakaian dan penyimpangan diluar batas kemampuan mesin sehingga mesin akan terjamin beroperasi dengan optimal dan terjaga dari kerusakan.

\subsection{Prioritas Alternatif Strategi Mitigasi pada Risiko Produk Jadi (output)}

Dari hasil penilaian dan pengolahan data pada alternatif strategi berdasarkan kriteria produk jadi (output) didapatkan bobot tertinggi yaitu sebesar 0,637 pada alternatif strategi strategi menjaga kualitas produk, alternatif strategi tersebut merupakan alternatif strategi prioritas yang paling berpengaruh dan paling penting untuk memitigasi risiko pada faktor produk jadi (output) yaitu adanya pesaing supplier beras.

Kualitas dari produk (barang/jasa) merupakan faktor dasar kepuasan konsumen dalam menentukan produk yang akan dibeli atau dipakai[4]. Pengendalian kualitas merupakan suatu aktifitas untuk menjaga dan mengarahkan agar kualitas produk perusahaan dapat dipertahankan sebagaimana yang telah diterapkan[4]. Oleh karena itu dengan menjaga kualitas beras akan mengatasi risiko adanya pesaing supplier beras, karena menjaga kualitas produk menjadi salah satu pertimbangan utama pelanggan dalam membeli suatu produk, berdasarkan hal tersebut dengan menjaga kualitas beras sesuai dengan harapan pelanggan maka UD Sido Muncul akan mendapatkan kepercayaan dan pelanggan akan melakukan pembelian secara continue sehingga keberlangsungan usaha akan terjaga, serta permintaan dan penjualan beras akan stabil.

\section{Kesimpulan dan Saran}

\subsection{Kesimpulan}

Berdasarkan hasil penelitian maka dapat ditarik kesimpulan sebagai berikut:

1. Risiko pada proses produksi beras secara umum dapat dibagi menjadi tiga faktor risiko yaitu faktor risiko bahan baku (input) diantaranya risiko gagal panen, keterlambatan waktu panen, kadar air padi tinggi, kualitas padi kurang baik akibat serangan hama, padi tercampur dengan padi jenis lain, pola tanam padi, pesaing pembeli 
padi, dan jenis padi tidak sesuai dengan permintaan. Faktor risiko proses produksi (process) diantaranya risiko lingkungan kerja yang tidak nyaman, keterlambatan proses produksi, bahan bakar habis pada saat proses proses produksi, pemadaman listri, kerusakan pada motor penggerak utama, kerusakan rangkaian alat penggilan padi, belt penghubung motor dengan rangkaian alat penggilingan putus, pemanasan oven tidak menyeluruh (tidak maksimal), kerusakan pada mesin oven, mesin dan alat bantu pengemasan rusak, bulir padi hancur pada saat penggilingan, dan kemasan beras habis pada saat proses produksi. Faktor risiko produk jadi (output) diantaranya kerusakan kemasan dan beras pada saat penyimpanan, keterlambatan pengiriman beras kepada pelanggan, pesaing supplier beras, beras hasil produksi tidak sesuai permintaan pelanggan, dan telatnya pembayaran dari waktu yang ditentukan oleh pelanggan.

2. Berdasarkan hasil perhitungan risiko pada faktor risiko bahan baku (input) didapatkan 1 risiko dengan kategori very high, 1 risiko dengan kategori high-very high, 1 risiko dengan kategori high, 2 risiko dengan kategori moderate-high, dan 3 risiko dengan kategori low-moderate. Risiko tertinggi pada faktor risiko bahan baku (input) yaitu pesaing pembeli padi dengan dengan bobot nilai FRPN sebesar 894. Pada faktor risiko proses produksi (process) didapatkan 1 risiko dengan kategori very high, 2 risiko dengan kategori high-very high, 2 risiko dengan kategori high, 3 risiko dengan kategori moderate-high, 1 risiko dengan kategori moderate, dan 3 risiko dengan kategori low-moderate. Risiko tertinggi pada faktor risiko proses produksi (process) yaitu kerusakan pada motor penggerak utama dengan dengan bobot nilai FRPN sebesar 883. Pada faktor risiko produk jadi (output) didapatkan 2 risiko dengan kategori high-very high, 2 risiko dengan kategori moderate-high, dan 1 risiko dengan kategori low-moderate.
Risiko tertinggi pada faktor risiko produk jadi (output) yaitu pesaing supplier beras dengan dengan bobot nilai FRPN sebesar 748.

3. Berdasarkan hasil perhitungan AHP didapatkan prioritas kriteria dan prioritas alternatif strategi untuk memitigasi risiko dari masing-masing faktor risiko yang dijadikan sebagai kriteria. Pada kriteria proses produksi (process) dengan bobot nilai 0,637 yaitu strategi pemeliharaan mesin secara rutin dengan bobot nilai 0,637. Pada kriteria bahan baku (input) dengan bobot nilai 0,258 yaitu strategi menjalin kemitraan dengan pelaku bisnis lainnya dengan bobot nilai 0,731 . Pada kriteria produk jadi (output) dengan bobot nilai 0,105 yaitu strategi menjaga kualitas produk dengan bobot nilai 0,637.

\subsection{Saran}

Berdasarkan hasil penelitian, saran yang dapat diusulkan kepada pemilik UD Sido Muncul agar dijadikan sebagai perbaikan dan rekomendasi untuk pekerja maupun penelitian selanjutnya adalah sebagai berikut:

1. Perlu dilakukannya pemeliharaan mesin secara rutin agar mesin dapat beroperasi dengan optimal,

2. Perlu dilakukannya menjalin kerjasama kepada para petani agar dapat menjamin ketersediaan bahan baku secara terusmenerus,

3. Perlu dilakukannya penjagaan dan peningkatan kualitas beras agar konsumen puas dan tidak beralih kepada supplier beras lainnya,

4. Sebaiknya pada penelitian selanjutnya dapat membahas tentang risiko biaya kegagalan produksi, pengembangan strategi, serta langkah-langkah taktis dan operasionalnya dan

5. Sebaiknya pada penelitian selanjutnyadapat menggunakan metode integrasi lainnya yang dapat digunakan dalammengidentifikasi, menilai, merancang dan memilih strategi untuk memitigasi risiko. 


\section{Daftar Pustaka}

[1] Badan Pusat Statistik, "Luas Panen dan Produksi Padi di Indonesia 2018,” 2018. [Daring]. Tersedia pada: https://www.bps.go.id/pressrelease/2018/1 0/24/1538/dengan-memperhitungkanpotensi-sampai-desember--maka-luaspanenpadi-di-indonesia-periode-januari--desember-2018-sebesar-10-90-jutahektar-dan-produks ipadi-sebesar-56-54juta-tongkg.html.

[2] Kementrian Pertanian, "Pemerintah Optimis Kalimantan Timur Swasembada Beras 2018,” 2018. [Daring]. Tersedia pada:

https://www.pertanian.go.id/home/?show $=$ news\&act=view\&id=1971.

[3] Badan Pusat Statistik, "Luas Panen dan Produksi Padi di Kalimantan Timur 2018," 2018. [Daring]. Tersedia pada: https://kaltim.bps.go.id/pressrelease/2018/ 11/01/331/luas-panen-padi-di-kalimantantimur-periode-januari--septem ber-2018sebesar-53-99-ribu-hektar-.html.

[4] J. P. Irawan, I. Santoso, dan S. A. Mustaniroh, "Model Analisis dan Strategi Mitigasi Risiko Produksi Keripik Tempe Model Analysis and Mitigation Strategy of Risk in Tempe Chips Production," vol. 6, no. 2, hal. 88-96, 2017.

[5] M. Basjir dan Suhartini, "Analisa Risiko Prioritas Perbaikan Kegagalan Proses Penjernihan Air Dengan Metode Fuzzy FMEA Kebutuhan manusia produksinya . Kegagalan adalah suatu kejadian dimana terjadi kondisi," vol. 3, no. 2, hal. 195210, 2019.
[6] S. Andiyanto, A. Sutrisno, dan C. Punuhsingon, "Penerapan Metode FMEA (Failure Mode and Effect Analysis) Untuk Kuantifikasi dan Pencegahan Resiko Akibat Terjadinya Lean Waste," vol. 6, no. 1, hal. 45-57, 2017.

[7] R. Sukwadi, F. Wenehenubun, dan T. W. Wenehenubun, "Pendekatan Fuzzy FMEA dalam Analisis Faktor Risiko Kecelakaan Kerja," vol. 6, no. 1, hal. 29-38, 2017.

[8] E. A. Winanto dan I. Santoso, "Integrasi Metode Fuzzy FMEA dan AHP Dalam Analisis dan Mitigasi Risiko Rantai Pasok Bawang Merah," vol. 22, no. 1, hal. 2132, 2017.

[9] A. E. Munthafa dan H. Mubarok, "Penerapan Metode Analytical Hierarchy Process Dalam Sistem Pendukung Keputusan Penentuan Mahasiswa Berprestasi," vol. 3, no. 2, hal. 192-201, 2017.

[10] A. Sasongko, I. Fitri Astuti, dan S. Maharani, "Pemilihan Karyawan Baru Dengan Metode Ahp (Analytic Hierarchy Process)," J. Inform. Mulawarman, vol. 12, no. 2, hal. 1858-4853, 2017.

[11] M. D. Prasetiyo, I. Santoso, dan S. A. Mustaniroh, "Strategi Pengelolaan Resiko Proses Produksi Yoghurt," vol. 18, no. 1, hal. 1-10, 2017.

[12] P. Tarigan, E. Ginting, dan I. Siregar, "Perawatan Mesin Secara Preventive Maintenance Dengan Modularity Design Pada PT . RXZ," vol. 3, no. 3, hal. 35-39, 2013. 